\title{
Fornuft og følelser: Norge og Russland etter Krim
}

\author{
Lars Rowe* \\ Seniorforsker, Fridtjof Nansens Institutt
}

\begin{abstract}
Sense and Sensibility: Norway and Russia after Crimea
After the annexation of Crimea, Moscow's relationship to the western world deteriorated dramatically. This was also true for the bilateral relationship between Russia and Norway. In this article, Norwegian perceptions of its eastern neighbor are discussed. Though clearly biased against Moscow, Norwegian politicians were simultaneously adamant in their emphasis on good neighborly relations with Russia and a will to protect areas of collaboration from spillover effects. This duality, it is argued, reflects a long-standing tradition in Norwegian Russia policies of balancing opposing elements. Though Norwegian media and policy makers were predominantly willing to perform this balancing act, the article also points to examples of unsubstantiated allegations made against "Russia" or "Russian actors". Originating from marginal outlets, such stories were accommodated by Norwegian mainstream media, which thereby contributed to creating a skewed - or at the very least uncorroborated - image of Russian intentions. From January 2017 onwards, the Russian embassy in Oslo engaged in the public debate. The embassy's contributions were unusual, more by virtue of their undiplomatic tone than by their political content. Despite current tensions, the author argues that the Norwegian-Russian bilateral relationship is now closer to a historical norm than at any point since the collapse of the Soviet Union.
\end{abstract}

Keywords: sanctions, threat perceptions, hybrid warfare, intelligence services, foreign policy debate

\section{Fornuft og følelser: Norge og Russland etter Krim}

I 2015 ble andre bind i historieverket om det bilaterale forholdet mellom Norge og Russland fra 1814 til 2014 lansert. Bindet bærer tittelen Naboer i frykt og forventning. Norge og Russland 1917-2014 (Holtsmark 2015), en tittel som er delvis identisk med en utgivelse fra 1996, nemlig Frykt og forventning. Russland og Norge $i$ det 20. århundre (Goldin \& Nielsen 1996). Begrepsparet «frykt og forventning» gir et signal om hva historikerne har observert i sine studier av det tosidige forholdet: at det her er emosjonene, ikke alltid fornuften, som dominerer. Man må anta at titlene først og fremst gjenspeiler det norske perspektivet. Det er vanskelig å forestille seg en russisk frykt for Norge. Det samme kan sies om forventninger. Asymmetrien i det norsk-russiske

^Kontaktinformasjon: Lars Rowe. Email: lars.rowe@fni.no 
forholdet har bare unntaksvis gitt plass til russisk bekymring og russiske forhåpninger. Det er i all hovedsak Norge som ser til Russland, ikke omvendt (Holtsmark 2015: 635-636).

Dagens debatt følger det samme mønsteret. Utviklingen i russisk politikk er, naturlig nok, bestemmende for utviklingen av det bilaterale forholdet. Norske forestillinger om Russland omgis stadig av sterke følelser. Der delelinjeavtalen som avklarte grensen i Barentshavet i 2010 avfødte enkelte overspente forventninger, er det frykten som har fått prege det norske ordskiftet om Russland etter annekteringen av Krimhalvøya i 2014. I praksis har dette medført at faktaorientert analyse og veloverveide utspill til tider har måttet vike plassen for en alarmisme som bygger på sviktende grunnlag.

Annekteringen av Krimhalvøya var en logisk konsekvens av et linjevalg som i mange år hadde preget russisk utenrikspolitikk. Etter de såkalte fargerevolusjonene i Georgia (2003), Ukraina (2004) og Kirgisistan (2005), anså det russiske lederskapet seg truet av anti-autoritære krefter. Faktorer som i perioder førte Russland nærmere vestlige stormakter, som felles kamp mot terrorisme, ble skjøvet i bakgrunnen. I stedet ble Vladimir Putins holdning til Vesten, og først og fremst USA, preget av sviktende tillit: Ville også Kreml bli utsatt for en liberal opposisjon som ikke bare fant ideologisk inspirasjon, men også finansiell støtte, i vestlige demokratier? Putin var åpenbart urolig for dette, og innrettet sin politikk og retorikk deretter (Zygar 2017: 121-143). Innenrikspolitisk innebar dette en klar dreining i autoritær retning, med repressiv lovgivning og vilkårlig håndhevelse rettet mot det (opposisjonelle) sivile samfunn som et av de fremste virkemidlene. Den autoritære dreiningen rammet også organisasjoner som samarbeidet med norske motparter (Skedsmo 2010: 22-55 og 67-74).

I utenrikspolitikken kom dreiningen først og fremst til syne retorisk, med den russiske presidentens tale til sikkerhetskonferansen i München i februar 2007 som et tidlig eksempel. Vladimir Putins budskap var sammensatt av elementer som etter hvert har blitt ledemotiver i russisk utenrikspolitisk retorikk: kritikk av vestlig dobbeltmoral, avsky for amerikansk arroganse, protest mot utvidelse av Nato og etablering av et anti-missilforsvar, ønske om en multipolar - i motsetning til en amerikanskdominert og unipolar - verdensorden og avvisning av demokrati-eksport fremmet av vestlig-finansierte frivillige organisasjoner som utidig innblanding i suverene staters indre anliggender (Putin 2007).

De knappe ti årene med en kombinasjon av autoritær russisk innenrikspolitikk og kraftige utfall mot vestlige motparter skulle muligens ha forberedt den norske offentligheten på at noe dramatisk var nær forestående. Men Ukrainas skjebne frambrakte likevel sjokk og vantro. Reaksjonene var forståelige. Det russiske folkerettsbruddet på Krim og den åpenbare støtten til øst-ukrainske separatister satte store deler av det politiske Norge i alarmberedskap. De påfølgende økonomiske og politiske sanksjonene mot Russland hadde tverrpolitisk støtte. Russland hadde satt seg utenfor det gode internasjonale selskap - Norges store nabo var blitt en rogue state som ikke bare tilsidesatte internasjonale normer, men som så ut til å handle i strid 
med sine egne interesser. Alt dette ble ledsaget av en russisk statspropaganda som la til grunn at landet slett ikke var en aggressor, men tvert imot var kringsatt av fiender.

Hvordan utviklet det norsk-russiske forholdet seg etter annekteringen av Krimhalvøya? Hvilke forestillinger om Russland fikk innpass i norsk offentlighet? Og hvilken respons kom fra russisk hold? Jeg vil i det følgende søke å besvare disse spørsmålene ved å undersøke norske medier, analysere norske politikeres omtale av Russland, og systematisk gjennomgå utsagn fra den russiske ambassaden i Oslo, som fra begynnelsen av 2017 søkte en aktiv rolle i den norske debatten. ${ }^{1}$

Innledningsvis identifiserer jeg to spesifikke russiske trusler som ble framhevet $\mathrm{i}$ det norske ordskiftet. Deretter vil jeg se nærmere på gjennomgangstonen i den norske mediedekningen av Russland, og norske politikeres uttalelser om nabolandet. Som vi skal se, er norsk tilnærming til Russland preget av en tradisjonsbunden dualitet: Mens en tenkt trussel fra nabolandet lenge har ligget til grunn for utformingen av norsk sikkerhetspolitikk, har det samtidig eksistert en tverrpolitisk enighet om å opptre imøtekommende overfor Russland. Men det finnes også en mer konfronterende tradisjon, som forstår russiske intensjoner som ensidig aggressive. Eksempler på slike alarmistiske tolkninger vil behandles separat. I forlengelsen av dette vil jeg se nærmere på russiske reaksjoner, idet det nettopp var påstander om russisk aggresjon som synes å ha framprovosert ambassadens debatt-iver. De russiske motforestillingene vil behandles i artikkelens nest siste seksjon. Til slutt vil jeg gi en kort betenkning om mulighetsrommet i det bilaterale forholdet slik det ser ut i dag. Jeg tar her utgangspunkt i at det norsk-russiske forholdet i skrivende stund ligger nærtopp til det som må oppfattes som en historisk normal, og at det bilaterale forholdet bør håndteres deretter.

\section{Trusselbilder}

«Den russiske fare» eller «russerfrykt» har lange tradisjoner i norsk offentlighet. Forestillingen om at den østlige stormakten i sin natur er ekspansiv, og at nabolandet Norge vil bli rammet av dette, har i perioder stått sterkt (Bones 2007: 37ff). Et klassisk eksempel fra førrevolusjonær tid er antakelsen om at Russland ønsket en isfri havn i nord, og at denne måtte erobres fra Norge. Trusseloppfatningen sto sterkt til tross for at russisk territorium bød på mange isfrie havnealternativer. Som Jens Petter Nielsen treffende skriver i sin artikkel om temaet: «[...] mot en slik bakgrunn fremstår forestillingen om at Russland strebet etter isfrie havner i Nord-Norge som en blek hallusinasjon» (Nielsen 1991).

${ }^{1}$ I tillegg til søk i databasen A-tekst - tidsmessig avgrenset til perioden 2014 til 2017, og tematisk avgrenset til artikler som omtaler det norsk-russiske forholdet - har jeg hatt stor nytte av Andrea Sofie Nilssens mastergradsavhandling "Norske premisser. En diskursanalyse av Regjeringens og mediers oppfatning av Russland» fra 2015 (Nilssen 2015), som meg bekjent er den eneste systematiske gjennomgangen av norske mediers og norske politikeres omtale av Russland etter Krim. Den russiske sidens reaksjoner dokumenteres og analyseres med utgangspunkt i ulike offentlig tilgjengelige kommentarer og pressemeldinger fra ambassaden i Oslo gjennom 2017. 
Dagens vurdering av en russisk militær trussel mot Norge er gjennomgående mindre hallusinerende, men har fremdeles innslag av alarmisme. Mange frykter at det russiske maktapparatet ikke deler verdisettet som ligger til grunn for internasjonal samhandling, men tvert imot ønsker å svekke den liberale verdensordenen. Russlands atferd bekrefter da også denne hypotesen i noen grad. Annekteringen av Krim gir alene grunnlag for å hevde at Russland har forlatt prinsippene om nasjoners territorielle ukrenkelighet slik de er nedfelt i folkeretten. Observasjonen styrkes videre gjennom analyser av utviklingen i russisk innenrikspolitikk, som gjennomgående avdekker reaksjonære trekk. ${ }^{2}$ Hvis man i tillegg legger til grunn at russiske utenrikspolitiske ambisjoner er ekspansjonistiske, ender man raskt opp med et bilde av et revansjistisk Russland som aktivt truer det internasjonale juridiske systemet. Vi befinner oss i det statsviterne Tormod Heier og Anders Kjølberg kaller en «ustabil usikkerhet», som kjennetegnes av et svekket USA og et Russland som utfordrer internasjonale spilleregler (Heier \& Kjølberg 2015: 177).

Som Heier og Kjølberg gjentatte ganger påpeker i ovennevnte publikasjon, er det imidlertid liten grunn til å tro at det ekspansjonistiske potensialet i den russiske reaksjonære utenrikspolitikken er særlig stort. Russland er simpelthen ikke sterkt nok, verken økonomisk eller militærteknologisk, til å utfordre sine vestlige motparter (ibid.: 179). Det er derfor nærliggende å anta at den russiske reaksjonen har et mer begrenset siktemål, nemlig å gjenopprette det Moskva oppfatter som en historisk normaltilstand: Russland skal spille en avgjørende rolle i internasjonal politikk, samtidig som landet selv skal definere sin innenrikspolitiske kurs uavhengig av vestlige bestrebelser for å legge til rette for en demokratisk utvikling i det russiske samfunnet (Hønneland \& Rowe 2010: 49-50; Renz \& Smith 2016). ${ }^{3}$ Ikke desto mindre har forestillinger om russisk ekspansjonisme et visst gjennomslag, også i Norge.

Jeg vil sortere norske forestillinger om et truende Russland i to delvis overlappende kategorier, nemlig den konvensjonelle og den hybride trussel. Særlig russisk styrkeoppbygging og øvelsesaktivitet i nord har gitt grunnlag for oppslag i norske medier som i noen grad maner fram et bilde av et ekspansjonistisk naboland som kan være villig til å invadere Norge. En slik konvensjonell trussel, der russiske styrker presenteres som et mulig redskap for invasjon, beskrives gjerne ved hjelp av dramatiserende metaforer som «den russiske bjørnen» og liknende (Nilssen 2015: 70). Videre benyttes overskrifter som signaliserer at faren for angrep er overhengende: «Nye og gamle

\footnotetext{
${ }^{2}$ Det finnes et utall akademiske og ikke-akademiske arbeider som viser dagens russiske regimes avvisning av liberale prinsipper. En opplisting av disse titlene er uhensiktsmessig her. Jeg vil imidlertid peke leseren i retning av Peter Pomerantsev (2014) og Mikhail Zygar (2016), som begge bidrar med originale innsikter fra et innsideperspektiv.

${ }^{3}$ Nettopp ambisjonen om å gjenvinne Russlands framstående posisjon i internasjonal politikk reflekteres i flere passasjer i Putins mye siterte tale etter annekteringen av Krim, som for eksempel: "Russland er en selvstendig og aktiv deltaker i internasjonal politikk og har, som andre land, nasjonale interesser. Disse må tas hensyn til og respekteres.» (Putin 2017).
} 
fiender truer Norge», «Bør Norge frykte Russland?», «Er Norge bedre forberedt i dag enn 9. april 1940?», «Putin viser muskler med 250 militærfly i lufta», «Slik kan Russland gå til angrep mot Norge», "Ekspert: Russland øvde på å innta Nord-Norge» (henholdsvis Dagbladet 2015; Aftenposten 2015; Aftenposten 2015b; Dagbladet 2015c; TV2 2015; TV2 2015b) er et knippe eksempler fra første halvår i 2015.

Det er likevel et annet aspekt ved den konvensjonelle trussel som synes vel så framtredende som alarmismen, nemlig avdramatiseringen. Her har nok den norske militære etterretningstjenesten spilt en viktig rolle. Gjennom sine årlige trusselvurderinger legger tjenesten mye av premissene for hvordan russiske utenrikspolitiske ambisjoner bedømmes i den norske offentligheten. Selve dokumentet "Fokus», som presenteres tidlig i hvert kalenderår, har gjennomgående vært preget av en evne til å balansere: På den ene siden underslår ikke tjenesten sin bekymring for hvilke ambisjoner Russland måtte ha overfor omverdenen. Samtidig fastslår tjenesten konsekvent at Russland ikke anses å ha planer om å invadere Norge. I den første trusselvurderingen etter annekteringen av Krim, som ble lansert i februar 2015, heter det for eksempel at «[t] il tross for de betydelige militære og sikkerhetspolitiske endringene i 2014 fastholder Etterretningstjenesten vurderingen av at Russland i dagens situasjon ikke utgjør noen militær trussel mot Norge» (Etterretningstjenesten 2015: 17). Etterretningstjenestens sjef har aktivt fremmet tjenestens funn og vurderinger i ulike fora. Dette har utvilsomt bidratt til å dempe det alarmistiske potensialet som ligger $\mathrm{i}$ en uhemmet pressedekning.

En annen dimension ved «den russiske fare» som har blitt trukket fram i den norske debatten, er altså det jeg vil kalle den hybride trussel. Generalløytnant og daværende etterretningssjef Kjell Grandhagen beskrev fenomenet som en «kombinasjonen av klassisk militærmakt og ukonvensjonelle midler». (Dagbladet 2015b). I Etterretningstjenestens trusselvurdering fra 2016, utbroderes begrepet ytterligere:

I tillegg til tradisjonelle militære virkemidler inkluderer den russiske tilnærmingen til mellomstatlige konflikter en helhetlig bruk av alle virkemidler tilgjengelige for staten. Virkemidlene inkluderer diplomatiske, økonomiske, informasjonsbaserte og teknologiske metoder, både av fordekt og åpen karakter. En konsekvens av den koordinerte bruken av virkemidler er at en motstander påføres samtidige og ulike utfordringer, som må håndteres i ulike deler av beslutningsapparatet (Etterretningstjenesten 2016: 21).

Man må anta at den russiske virkemiddelbruken $\mathrm{i}$ forbindelse med annekteringen av Krimhalvøya, som blant annet inkluderte desinformasjonskampanjer, fordekt russisk militær tilstedeværelse og et russisk diplomatisk korps i høygir, ble opplevd som så dramatisk og muligens også unikt at man tok i bruk dette begrepet. Hybridkrig hadde allerede blitt eksplisitt omtalt av den russiske generalstabssjefen Valerij Gerasimov som et sett virkemidler med høy effektivitet om de kombineres med militær maktbruk (Gerasimov 2013). Enkelte har på bakgrunn av begivenhetene som ledet fram mot den russiske annekteringen av Krimhalvøya, og dessuten Gerasimovs artikkel, konkludert at hybridkrig er et framtredende aspekt ved russisk 
konflikthåndtering. ${ }^{4}$ Det faktum at Gerasimov i sin artikkel, og i foredraget den var basert på, faktisk beskrev det han oppfattet som vestlig bruk av hybride virkemidler og at det russiske forsvaret var dårlig forberedt på å møte denne nye trusselen fra vest, underkommuniseres (Renz 2016; Bartles 2016). De fleste elementene som beskrives som «hybride» er kjente fra før. Både diplomatisk press, (des-)informasjonskampanjer og fordekt militær virksomhet har i tidligere konflikter blitt brukt i kombinasjon med hverandre.

Men noe er nytt. Det hybride virkemidlet som kanskje har blitt viet mest oppmerksomhet i Norge og andre vestlige land, er muliggiort av den teknologiske utviklingen de siste tiårene. Infiltrasjon og manipulering av elektroniske nettverk, eller cyberkrig, har hyppig blitt tilskrevet russiske regjeringskontrollerte aktører. Det fremste eksemplet var påstandene om russiske datainnbrudd i Demokratenes e-postserver i USA og etterfølgende manipulering av det amerikanske presidentvalget sommeren og høsten 2016. Heller ikke Norge har blitt spart for slike angrep, hevdes det fra etterretningshold. Cyberangrep mot Norge har skjedd og vil skje igjen, ifølge den norske sivile sikkerhetsstjenesten (PST). I sin seneste trusselvurdering fastslår PST lakonisk at "[d] et vil bli gjennomført avanserte datanettverksoperasjoner mot norske myndigheter, IKT-tilbydere, teknologimiljøer og mot aktører med ansvar for kritisk infrastruktur også i 2017» (Politiets sikkerhetstjeneste 2017: 9).

En fellesnevner for det som her er betegnet som den hybride trussel er at den i all hovedsak tilskrives Russland, til tross for at skyldspørsmålet i beste fall er uavklart. Et annet særtrekk er at trusselen i seg selv synes vanskelig å definere, også for dem som arbeider for å motvirke den. Oberstløytnant Geir Hågen Karlsen ved Forsvarets stabsskole uttrykker seg slik: «I dag er det nesten enklere å si hva hybrid krigføring ikke er. Hvis vi skal nærme oss en definisjon, må det være at det dreier seg om krig eller konflikt der andre virkemidler enn de militære er de viktigste» (Forsvaret 2017: 66).

Kombinert med den tradisjonelle norske «russerfrykten" gir fenomenet hybridkrig, og dets flytende avgrensing, grobunn for vidtrekkende tolkninger av ulike situasjoner. Som Renz \& Smith (2016: 12) påpeker, åpner begrepets uklarhet for analyser som identifiserer nesten ethvert russisk tiltak som en del av en større hybridkrig-kampanje. Forfatterne konkluderer at begrepet verken er brukbart i akademisk analyse eller som utgangspunkt for politikkutforming (ibid.: 13). Ikke desto mindre synes forestillinger om russisk hybridkrig altså å ha appell, både i enkelte akademiske miljøer og blant forsvarsplanleggere. Nedenfor skal vi se noen norske eksempler på hvordan uklare forestillinger om årsaksforhold, men klare forestillinger

\footnotetext{
${ }^{4}$ Bettina Renz diskuterer anvendelsen av hybridkrig-begrepet $\mathrm{i}$ artikkelen «Russia and 'hybrid warfare'", der hun blant annet henviser til Natos parlamentarikerforsamlings beskrivelse av russisk hybridkrig som «a new strategic challenge» og hvordan forsvarskomiteen i det britiske underhuset konkluderte med at den russiske virkemiddelbruken fordret ny doktrineutvikling innenfor Natosystemet. Se Renz (2016).
} 
om skyldspørsmål kan resultere i forhastete slutninger om russiske intensjoner, koordineringsevner og virkemidler.

\section{Den norske dualiteten}

Som antydet inntok norske politikere umiddelbart en fordømmende holdning overfor Russland etter folkerettsbruddet på Krimhalvøya. Denne unisone kritikken ble primært uttrykt ved at et samlet politisk Norge stilte seg bak sanksjonene som ble iverksatt av alliansepartnere i Nato i harmoni med EUs straffetiltak. Fordømmelsen fikk også retoriske utslag. Norske regjeringsmedlemmer var klare i sin oppfatning om at russisk opptreden overfor Ukraina, både på Krim og senere i Donbas, var uakseptabel. Den mellomstatlige kontakten mellom Norge og Russland ble på det nærmeste suspendert. De første 20 månedene etter annekteringen av Krim hadde ingen norske politikere møter med sentralt plasserte russiske motparter. Da bilaterale samtaler i desember 2015 ble gjenopptatt, var det innenfor rammen av det langvarige miljøsamarbeidet (Klima- og miljødepartementet 2015), som har få eller ingen tematiske forbindelser til situasjonen i Ukraina.

Forsvarsminister Ine Marie Eriksen Søreide og utenriksminister Børge Brende har vært konsistente i sine uttalelser om Russland etter at Ukraina-konflikten oppsto. Regjeringens budskap har vært flersidig: Russland er stridens aggressor, og opererer med utgangspunkt $i$ at utenrikspolitikk i sin natur er et nullsumspill med lite eller intet rom for interessefellesskap. Regjeringen har dessuten vektlagt at Russlands handlinger viser at Moskva fremmer en alternativ verdensorden og utgjør en trussel mot folkerettsregimet som ble etablert etter andre verdenskrig. Regjeringens svar, slik det formuleres av Søreide, Brende og statsminister Erna Solberg, er styrking av Nato og videreutvikling av samholdet mellom liberale demokratier (Nilssen 2015: 35-54).

Samtidig som Regjeringen har uttrykt entydig fordømmelse av russiske handlinger i Ukraina, har den vært påpasselig med å understreke samarbeidspotensialet i det bilaterale forholdet. Dette identifiserer Andrea Sofie Nilssen (2015) som den norske «nabodiskursen", som vektlegger det norsk-russiske interessefellesskapet i nord. Talspersoner for Regjeringen har konsekvent framhevet nødvendigheten av å skjerme ulike norsk-russiske samarbeidsflater for det man kan kalle «storpolitisk smitte». I en kronikk i Nordlys i august 2017 ga Børge Brende uttrykk for nettopp dette, idet han beskrev russlandspolitikkens dualisme med utgangspunkt i «to stolper»:

Det er avgjørende for Norge at samhandlingen er basert på folkeretten, ikke på den sterkestes rett. Derfor er Russlands brudd på folkeretten så alvorlige. Og derfor måtte vi reagere, blant annet ved å innføre restriktive tiltak slik også våre allierte og partnere har gjort. Dette er den første stolpen. Norges russlandspolitikk ble altså justert på konkrete punkter som respons på Russlands folkerettsstridige annektering av Krim og destabilisering av Øst-Ukraina. Årsaken ligger ikke i det bilaterale forholdet mellom Norge og Russland. Vi har fortsatt et godt og ryddig naboforhold til Russland, og vi har videreutviklet det bilaterale samarbeidet. Dette er den andre stolpen (Brende 2017). 
Nilssen (2015: 54) viser at denne "andre stolpen», eller «nabodiskursen», befinner seg $i$ et hierarkisk forhold til Regjeringens "første stolpe», eller den "vestlige diskursen», og at sistnevnte har forrang. Dualiteten er imidlertid ikke av ny dato.

Som den observante leser vil kunne konstatere, korresponderer tosidigheten til en viss grad med begrepsparet "frykt og forventning", som ble introdusert innledningsvis. Ytterligere en beslektet dualitet i norsk russlandspolitikk, uttrykt gjennom et annet begrepspar, er ambisjonene om å oppnå «avskrekking og beroligelse», som tilskrives den tidlige etterkrigstidens norske «avskjermingspolitikk». I korte trekk dreide dette seg om en linje der norsk sikkerhet ble ivaretatt av Natos avskrekkende forpliktelser overfor Norge, samtidig som norske myndigheter begrenset alliert aktivitet på eget territorium i den hensikt å berolige den sovjetiske naboen (Eriksen \& Pharo 1997: 85ff).

Disse historiske referansene framstår relevante for både observatører og politikere i det norske ordskiftet i dag. Balansepolitikken har stadig vært framme i den norske debatten etter Russlands annektering av Krim. I januar 2017 fastslo forsvarsminister Ine Marie Eriksen Søreide at «[a]vskrekking og beroligelse har vært og vil i overskuelig fremtid være parallelle elementer i norsk sikkerhetspolitikk» (Søreide 2017). Forsvarsministerens presisering kom etter at avisen Nordlys på lederplass hadde etterlyst større grad av beroligelse og mindre grad av avskrekking (Nordlys 2017).

Berettigelsen av både avskrekking og beroligelse i norsk russlandspolitikk var og er allment akseptert. I den grad uenighet har oppstått, har den dreid seg om vektleggingen av det ene i forhold til det andre. I ovennevnte leder mente Nordlysredaksjonen åpenbart at Regjeringen overspilte avskrekkingselementet og underprioriterte betydningen av beroligelse. Den umiddelbare bakgrunnen for kritikken var amerikansk deltakelse i øvelsesaktivitet på norsk jord, og ikke minst etableringen av en permanent ordning for rullering av amerikanske marinesoldater på Værnes i Trøndelag (ibid.). Sammen med Norges eventuelle deltakelse i Natos missilforsvar, er det usikkerhet omkring norsk basepolitikk som har vekket sterkest reaksjoner på russisk side: Er Norge i ferd med å forlate sine «selvpålagte restriksjoner» i nord, som siden 1949 har fungert som et beroligende middel overfor naboen i øst, spør man seg i den russiske utenrikstjenesten (Den russiske ambassaden 2017).

Det er lite som tyder på at dagens norske regjering underkjenner behovet for beroligelse av Russland. Likevel ser det økte spenningsnivået i kjølvannet av Krimkonflikten ut til å utfordre enkelte norske regjeringsmedlemmers evne til å uttrykke seg tilstrekkelig diplomatisk. Et eksempel er Ine Marie Eriksen Søreides intervju med den amerikanske tv-stasjonen $C N N$ i februar 2015, der hun fastslo at en normalsituasjon i forholdet til Russland aldri kan gjenopprettes (CNN 2015). Utsagnet var i seg selv uklart med hensyn til hvilken "normalitet» hun sammenliknet med, og dessuten uklokt med tanke på signaleffekten overfor Russland, noe som vil diskuteres avslutningsvis i denne artikkelen. Et senere eksempel, som vanskelig kan forstås som noe annet enn et grovt retorisk feilsteg, var Erna Solbergs avvisning av 
et åpent brev fra den russiske ambassaden i Oslo som «eksempel på russisk propaganda som gjerne ofte kommer når det er stort fokus på for eksempel sikkerhetspolitikk» (VG 2017).

Søreide og Solbergs uttalelser reflekterer nok til en viss grad at Russlands handlinger i Ukraina har åpnet opp for bombastiske tolkninger av nabolandet i øst. Den sedvanlige diplomatiske formen har i enkelte ubetenksomme øyeblikk måttet vike i utsagn der det høres som regjeringsmedlemmenes skuffelse og frustrasjon over russisk selvhevdelse skinner gjennom. Enkelte observatører har da også hevdet at Regjeringens linje overfor Russland har vært for konfronterende (NRK 2017b). Slik kritikk har endog kommet fra framstående medlemmer av Fremskrittspartiet, Høyres koalisjonspartner i den sittende regjeringen. Kritikken har dog primært blitt uttrykt av talspersoner uten ministerposter (Minerva 2017).

I så måte er det naturlig å identifisere en tendens til at uklarhet i en sentral del av norsk utenrikspolitikk, russlandspolitikken, utfordrer den etablerte tverrpolitiske enigheten om Norges forhold til omverdenen. Siden den norske signeringen av Atlanterhavspakten i 1949, har norsk utenrikspolitisk debatt i all hovedsak ligget død. Bare unntaksvis har norske fløypartier, som Sosialistisk Folkeparti (senere Sosialistisk Venstreparti (SV)), arbeidet for alternative veivalg. Det som var igjen av SVs utenrikspolitiske dissens svant raskt hen da partiet oppnådde regjeringsmakt i 2005. Den motsatte fløyens største parti, Fremskrittspartiet, ser heller ikke ut til å ønske å etablere en stabil utenrikspolitisk opposisjon til sin egen regjering. Det er derfor for tidlig å konkludere med at konsensustiden i norsk utenrikspolitikk er forbi, selv om dagens labilitet i internasjonale forbindelser skaper uro og usikkerhet også i Norge.

\section{Alarmen går!}

Som nevnt i ovenstående gjennomgang av ulike sider ved trusselbildet, er hovedinntrykket at norsk presse har maktet å unngå en altfor alarmistisk dekning av Norges forhold til Russland etter Krim. De fleste nyhetssakene synes å ta inn modererende elementer som at Russland ikke anses å ha ekspansjonistiske ambisjoner overfor Norge. Slike avdramatiseringer, som gjerne er videreformidlet fra norsk militær etterretning, kommer riktignok under høydramatiske overskrifter, slik jeg illustrerte innledningsvis. Men i noen tilfeller har det modererende elementet vært fraværende, samtidig som en ensidig alarmisme har fått legge premissene for tolkninger av russiske ambisjoner, intensjoner og virkemidler. Vi skal i denne delen se nærmere på noen av sakene som har fulgt denne oppskriften.

Høsten 2015 ble grenseovergangen mellom Norge og Russland ved Storskog gjenstand for stor oppmerksomhet. De norske grensemyndighetene på stedet, som i all hovedsak hadde regulert ordinær gods- og turisttrafikk siden åpningen av grensen i 1992, ble stilt overfor en eksplosjonsartet økning i antallet migranter som søkte opphold i Norge, og dermed innreise til hele Schengen-området. I takt med den generelle 
oppgangen i migrasjonstrafikken fra Midtøsten og afrikanske land mot Europa hadde også dette nordlige grensepunktet opplevd et visst press fra et høyere antall migranter gjennom første halvdel av 2015. Det var imidlertid først fra slutten av august til midten av november at tallene skjøt i været. Fra å ha prosessert et gjennomsnittlig antall på 16,5 asylsøknader i året i perioden 2003 til 2014, hadde grensestasjonen med ett 5500 nye søknader om opphold å forholde seg til (Moe \& Rowe 2016).

Flere deltakere i ordskiftet var sikre på at migrasjonsstrømmen var initiert og styrt av russiske myndigheter. De antok at Russland ønsket å straffe Norge for landets tilslutning til EUs sanksjoner. Enkelte hevdet at flyktningestrømmen måtte ses som et ledd $\mathrm{i}$ en russisk hybridkrig mot Norge - flyktningene ble kanalisert mot Norge for å destabilisere landet, het det (Aldrimer 2015; Dagsavisen 2015; Aftenposten 2015c). Alternative og mer tilforlatelige forklaringer på den overraskende flyktningestrømmen mot Storskog høsten 2015, som at den såkalte «arktiske ruten» var et mindre risikabelt og rimeligere alternativ til middelhavsruten, hadde lite giennomslag. "Hybridkrig-teorien» forutsatte et svært samordnet, enhetlig og rasjonelt russisk myndighetsapparat som på kort tid er i stand til å koordinere bevegelsene til store grupper mennesker som ikke har Russland som sitt hjemland. Gyldigheten av en slik forestilling er i beste fall omtvistet (Hønneland 2016; Renz 2016). Våren 2016 publiserte undertegnete en artikkel med kollega Arild Moe som bestred grunnlaget for «hybridkrig-teorien» og framholdt en alternativ forklaringsmodell (Moe \& Rowe 2016). Den sto i ettertid uimotsagt.

Men nettopp denne typen forestillinger om et effektivt russisk myndighetsapparat som bedriver fordekt sabotasje har fått et fotfeste i det offentlige ordskiftet om Russland etter Krim. Det er kort vei fra at noe går galt eller noe uventet skjer til at Russland får skylden. Igjen er det fristende å vise til USA, som i den alarmistiske dekningen av Russland har vært toneangivende. Tilbøyeligheten til å tilskrive utfallet av det amerikanske presidentvalget til russisk påvirkningsaktivitet er påfallende udokumentert. En klarttenkende kommentator, den Putin-kritiske skribenten Masha Gessen, skrev lite flatterende om amerikanske etterretningsinstitusjoners offentlige fellesrapport (Office of the Director of National Intelligence 2017): «The fog is not coincidental: if the report's vague assertions were clarified and its circular logic straightened out, nothing would be left» (Gessen 2017). Gessen påpekte ikke bare den amerikanske etterretningsrapportens tilkortkommenheter, men også den amerikanske pressens naive videreformidling av budskapet.

Den samme tendensen til ukritisk å videreformidle udokumenterte påstander fra etterretningsmiljøer har vist seg i norske media. Særlig har PSTs rapporter og uttalelser om russisk cyberkrigføring fått stor plass. Et av mange illustrerende eksempler er hvordan nyheten om at det skulle ha foregått et "[r] ussisk hackerangrep mot Norge» i februar 2017, der PSTs mistanker videreformidles av norske medier (NRK 2017a). Det typiske mønsteret, som også forekom her, er at slike saker i beste fall bygger på indisier om at «Russland» eller «russiske miljøer» står bak, men at håndfast dokumentasjon er fraværende. 
Mitt poeng her er ikke at russiske myndigheter skal fritas for mistanke om at de fører ulike former for påvirkningskampanjer og bedriver varianter av hacking. Den åpenbare desinformasjonen som ledsaget operasjonene på Krim og i Donbas, samt russiske cyberangrep mot Estland og Georgia i henholdsvis 2007 og 2008 er alene nok til å fastslå at det russiske virkemiddelapparatet er omfattende. Likevel er det grunn til bekymring når kravene til dokumentasjon synes å ha blitt svekket i deler av nyhetsjournalistikken, og da særlig den som omhandler etterretningsorganers påstander om russiske utfall mot vestlige land. Man kan her anføre at etterretningstjenestenes konspiratoriske natur gjør deres rolle som premissleverandører i den offentlige debatten umulig. I mange tilfeller må slike tjenester beskytte både sine kilder og metoder, og blir dermed henvist til å formidle udokumenterte påstander. Det er samtidig liten tvil om at deres funksjon som voktere av vestlige demokratiske samfunn er viktig. Spørsmålet bør altså ikke være hvorvidt slike tjenester utfører et nødvendig samfunnsoppdrag, men snarere om den inkriminerende informasjonen de besitter hører hjemme i det offentlige rom, all den tid den ikke lar seg verifisere. Uavhengig av hvilket svar man kommer fram til, gjenstår ett faktum: Rommet for norske mediers spekulasjon om russiske ambisjoner, intensjoner og virkemidler har blitt stort etter annekteringen av Krim.

Etterretningsinformasjon formidles tidvis også indirekte. Nettstedet aldrimer.no har blant annet publisert påstander om at et antall fastleger basert i Nord-Norge er rekruttert av russisk etterretning for å frambringe sensitive opplysninger om forsvarspersonell og deres nærmeste (Aldrimer 2016). Redaktøren for nettstedet har også hevdet at deler av den nordnorske befolkningen «har en lojalitet som går mer i retning av Russland enn til sentrale norske myndigheter i Oslo» (NRK Finnmark 2016). Disse påstandene, som naturlig nok avfødte sterke reaksjoner, har gjennomgående vært ledsaget av henvisninger til uidentifiserte etterretningskilder. Nettstedets journalister påberoper seg et kildevern som umuliggjør reell etterprøving, men påstandene videreformidles av større mediebedrifter og svirrer dermed like fullt i luften.

Men det er ikke bare i media at kald analyse har måttet vike plassen for heftige reaksjoner og ubetenksomme tiltak. Alarmismen har tidvis hatt gode vekstvilkår langt inn i norske regjeringskorridorer. Jeg har allerede nevnt statsminister Solbergs og forsvarsminister Eriksen Søreides retoriske blundere. Et mer alvorlig eksempel, som på lengre sikt kan skape problemer for Norges legitimitet som suverenitetshevder på Svalbard, kom i kjølvannet av den russiske visestatsministeren Dmitrij Rogozins uanmeldte besøk til øygruppa den 18. april 2015. Rogozin, en av mange russiske myndighetspersoner som ble rammet av sanksjonsregimets reisebestemmelser etter annekteringen av Krim, ønsket muligens å provosere da han valgte å lande i Longyearbyen. Men, som borger av en av Svalbardtraktatens signatarmakter hadde han «like rett til adgang og ophold", slik traktaten foreskriver (Svalbardtraktaten 1920). Norske utenriksmyndigheter lot seg provosere: Utenriksminister Børge Brende kalte Russlands ambassadør inn på teppet og gjorde 
det klart at Rogozin var en uønsket person ikke bare i fastlands-Norge, men også på Svalbard. ${ }^{5}$

Man kunne sett for seg at norske utenriksmyndigheter lot saken ligge med dette, eller kanskje enda klokere: forholdt seg rolig fra første stund. Rogozins besøk ville raskt blitt glemt i rekken av provokative og symbolske russiske framstøt. I stedet igangsatte Regjeringen et lovarbeid med sikte på å avskjære framtidige besøk av uønskete personer til Svalbard. Forskriftsendringen, som først var av midlertidig karakter, trådte i kraft i sin permanente form 1. september 2016. Teksten gir Sysselmannen ryggdekning for å bortvise personer som «omfattes av internasjonale restriktive tiltak som inneholder reiserestriksjoner som Norge har sluttet opp om, og som er gjennomført for øvrige deler av Kongeriket Norge» (Endringer i forskrift 2016).

Den norske reaksjonen på Rogozins provokasjon kan ved første øyekast synes rimelig og handlekraftig. Men i den grad Regjeringen feirer, kan den fort stå overfor en pyrrhosseier: Forskriftsendringens juridiske grunnlag er diskutabelt. Mens norske myndigheter vil argumentere for at teksten, i likhet med annen norsk lovgivning, er i pakt med Svalbardtraktatens bestemmelser, vil russiske myndigheter hevde at den står i strid med traktatens prinsipp om likebehandling av signatarmaktenes borgere (Svalbardposten 2015). I skrivende stund er forskriftsendringen ikke kommet til anvendelse. Men i det sensitive politiske spillet om ressursforvaltning og jurisdiksjon på og rundt Svalbard, har russiske myndigheter blitt tildelt et strategisk kort de når som helst kan velge å spille ut. Om behovet for å diskreditere norsk suverenitetshevdelse skulle oppstå, kan Rogozin eller en tilsvarende uønsket russisk person reise til Longyearbyen og hevde seg feilaktig behandlet når Sysselmannen utøver det Norge mener er hennes forskriftsmessige rett til å bortvise vedkommende. Det kan i lys av denne muligheten neppe konkluderes med at forskriftsendringen var et sindig og klokt tiltak, særlig tatt $\mathrm{i}$ betraktning at Rogozins besøk antakelig ville blitt glemt uten konsekvenser om det hadde blitt ignorert av norske myndigheter.

\section{Den russiske ambassaden debatterer}

Russiske og sovjetiske utenriksmyndigheter har lenge, noen vil hevde siden Peter den stores tid, forstått seg selv i lys av den vestlige verden: Avhengig av utviklingen i Europa og senere USA, og ikke minst av hvilken trend som til enhver tid har vært toneangivende i russisk politikk, har talspersoner for Moskva stått i en mer eller mindre motsetningsfylt stilling til omverdenen (Tsygankov 2010: 2ff). Det skarpe motsetningsforholdet mellom Russland og Vesten etter annekteringen av Krim handlet raskt om mer enn bare Ukrainas skjebne. Sett fra Vladimir Putins ståsted befant Russland seg i eksistensiell kamp mot ytre fiender, og innlemmelsen av Krim var bare

\footnotetext{
${ }^{5}$ Rogozins besøk og dets etterspill ble omtalt i en rekke medier. En del av nyhetssakene med lenker til ulike medier er samlet på NRK.no (2015). Framstillingen av saksforløpet er i hovedsak basert på informasjon derfra.
} 
ett av mange ledd i fedrelandsforsvaret. I en revansjistisk tale, spekket med historiske referanser, malte han et bilde av et reaktivt Russland som var presset til det ytterste av omverdenen (Putin 2014). Putins tolkninger av perioden etter Sovjetunionens sammenbrudd var en foraktfull avvisning av vestlig politikk overfor Russland (Charap $\&$ Colton 2017). Presidentens lesning av nyere historie satte tonen for den russiske utenrikstjenestens retoriske linje i tiden som kom.

For russiske myndigheter er Norge først og fremst en lite ruvende motspiller $\mathrm{i}$ internasjonal politikk. Norge som nasjon nyter beskjeden strategisk interesse i Moskva utover det faktum at landets territorium utgjør Natos nordflanke. Norge har riktignok legitime interesser, og i kraft av havretten uforholdsmessig stor innflytelse, $\mathrm{i}$ arktiske farvann. Men også dette vil nok av Moskva primært vurderes i lys av Norges Nato-medlemskap.

Uttalelser om Norge fra den russiske utenrikstjenesten gienspeiler både Natodimensjonen og den offisielle russiske forståelsen av nyere internasjonal historie slik den har blitt presentert av det russiske toppsjiktet. Likevel har en del russiske reaksjoner på utviklingen i Norge vært oppsiktsvekkende i sin form. Fra januar 2017 begynte den russiske ambassaden i Oslo å publisere «pressemeldinger» eller «kommentarer", som utmerket seg med sin konfronterende linje og udiplomatiske tone. Denne informasjonsstrategien, som må sies å utgiøre en uvanlig praksis fra en diplomatisk stasjon, kan muligens tilskrives ambassadør Teimuraz Ramisjvili, som tiltrådte i stillingen som ambassadør i november 2016.

I perioden mellom januar og november 2017 kom det tretten ulike meldinger som tok opp Russlands forhold til Vesten generelt og Norge spesielt. Temaer som Natos "provoserende uttalelser» og "militære forberedelser», Natos rakettskjold og Norges eventuelle bidrag til dette, norsk pressedekning av Russland, russisk visumnekt til norske politikere og journalister, påstander fra PST, alliert øvingsaktivitet og utstasjonering av Nato-mannskaper på norsk jord og situasjonen for flyktninger på det norsk-russiske grensepunktet Storskog ble omtalt (Den russiske ambassaden 2017a, b, c, d, e, g, h, i, j, k og 1). I tillegg kom en lengre utredning av ambassadens syn på tilstanden i det bilaterale forholdet mellom Norge og Russland (Den russiske ambassaden 2017f). ${ }^{6}$

Det er særlig to elementer som går igjen i ambassadens omtale av Nato: Alliansens utvidelse østover etter Sovjetunionens sammenbrudd og utviklingen av et rakettskjold (BMD). Det hevdes at Nato systematisk og i strid med løfter gitt til russiske myndigheter utbygget sine militære kapasiteter nærmere Russlands grenser, og konsekvent avviste russiske forslag om nedrustning og avspenning. Dette, og særlig Natos utbygging av et rakettskjold, forrykker maktbalansen mellom øst og vest,

${ }^{6}$ Dette er ikke en uttømmende liste over pressemeldingene fra Russlands ambassade i perioden, men et utvalg gjort på bakgrunn av at alle meldingene henvendte seg mer eller mindre direkte til opinionen og slik tok sikte på å levere et bidrag til den norske samfunnsdebatten. Alle er skrevet på norsk. 
heter det (Den russiske ambassaden 2017a og b). I en melding som spesifikt omtaler eventuell norsk deltakelse i rakettforsvaret, sies det at «USAs og NATOs handlinger, Norge inkludert, vil kunne føre til problemer ikke bare i nord, men de kan undergrave den strategiske stabiliteten, noe som kan få katastrofale følger for sikkerheten både i Europa og verden over» (Den russiske ambassaden 2017g). Tonen i denne passasjen er som vi ser skarp, og uvanlig udiplomatisk til å komme fra en ambassade. Valget av format, en offentlig tilgjengelig pressemelding, antyder at den russiske ambassaden her har ønsket å la den norske offentligheten få innsikt i russiske synspunkter.

Inntrykket av at den russiske ambassaden hadde ambisjoner om å delta aktivt $\mathrm{i}$ den løpende debatten i Norge ble forsterket av en melding senere i januar 2017, der en nyhetssak fra NRK om hvordan russiske diplomater angivelig skal ha søkt å påvirke nobelkomiteens beslutningsprosess ble kritisert. PST var artikkelens hovedkilde (NRK 2017c). Ambassadens reaksjon var tydelig: «Forsøk på å se helt vanlige, kanskje endog rutinepregede diplomataktiviteter som 'russisk etterretningsvirksomhet' virker paranoid.» Som for å aktualisere sin kritikk for den norske opinionen antydet ambassaden at norske medier og norsk etterretning hadde tvilsomme motiver:

Det er norske skattebetalere, ikke vi, som må avgjøre hvor profesjonell og faglig egnet etterretningstjenester er. Men slik [ved å skape skremmebilder av Russland] er det åpenbart enklere å rettferdiggjøre sin eksistens og en komfortabel finansiering. I den senere tid er det blitt på moten å forklare egne fiaskoer med Russlands «informasjonsoperasjoner». I det store og det hele ser vi bestrebelser på å skape et negativt inntrykk av Russland. [...] I alle fall er det lettere å skremme den egne befolkningen med den «russiske trussel», «informasjonsoperasjoner av russiske etterretningstjenester» og «hybridkriger» enn å bekjempe terrorister og ekstremister (slik Russland og Syria giør) eller finne nyhetssaker som virkelig er viktige for landene våre (Den russiske ambassade 2017c).

Ambassadens kritiske holdning til PST og norske medier ble gjentatt flere ganger. I februar beskyldte ambassaden PST for å drive «heksejakt» på russiske tjenestemenn (Den russiske ambassaden 2017e). I oktober reagerte diplomatene mot en nyhetssak i TV2 som omtalte angivelige påvirkningsoperasjoner. Foruten å påpeke at TV2-sakens innhold manglet dokumentasjon, leste ambassaden PSTs rolle som hovedkilde også her i lys av etterretningsorganisasjonens posisjonering i det politiske landskapet: «Vi skjønner hva slike innkast er motivert med. Spesialtjenestene må tiltrekke seg oppmerksomhet $\mathrm{i}$ forkant av dannelse av ny regjering, gjennomgang av budsjett og endringer i lovverket for å tildele dem ekstra fullmakter [sic]». Ambassaden mer enn antydet en binding mellom PST og den ansvarlige journalisten: «Ekte journalister burde være interessert i fakta, ikke spekulasjoner, hvis man ikke er fast ansatt i en sikkerhetstjeneste, sant nok [sic]» (Den russiske ambassaden 2017k).

Ambassaden opplevde i februar 2017 et behov for å klargjøre sin posisjon i en sak der to norske stortingsrepresentanter ble nektet innreise til Russland i forbindelse med et delegasjonsbesøk til Moskva. Innreisenekten var et motsvar til de norske reiserestriksjonene mot et antall russiske enkeltpersoner, derunder Rogozin (se ovenfor). Interessant nok begrunnet Den russiske ambassaden innreisenekten mot stortingsrepresentantene også med den ovenfor omtalte forskriftsendringen vedrørende 
innreise til Svalbard, som den oppfattet som "permanent diskriminerende for russiske statsborgere som ønsker å reise til Spitsbergen» (Den russiske ambassaden 2017d). I en senere melding, som omtalte et innreiseforbud mot en norsk journalist, ble de samme begrunnelsene anført. Denne gangen tillot ambassaden seg å komme med noen utdypende bemerkninger:

Vi har gientatte ganger advart mot bruk av sanksjoner, for dette redskapet er tveegget
og vil uunngåelig slå tilbake mot en som innleder dem. [...] Alt avhenger av våre norske
partnere, deres evne til å forstå at denne situasjonen er åpenbart skadelig for dialog og
deres villighet til å drøfte gjensidig avlysning av slike reaksjoner [sic] (Den russiske am-
bassaden $2017 \mathrm{~h}$ ).

Gjennomgående er budskapet i disse meldingene kjent stoff. Det er derfor ikke innholdet, men den direkte formen og kanaliseringen mot den norske offentligheten som overrasker. Fraværet av diplomatisk etikette og det faktum at flere av meldingene griper direkte eller indirekte inn i løpende norske diskusjoner (om Norges forhold til Russland, om Norges forhold til Nato, om PSTs rolle som overvåker, om bruk av norske skattepenger, osv.), styrker inntrykket av at Den russiske ambassadens siktemål er å gi sitt besyv med i norsk offentlig debatt. De russiske diplomatene appellerer til den norske opinionens kritiske sans, og framstiller seg selv som folkets allierte i striden mot sikkerhetstjenestenes og medienes demonisering av Russland. Det kanskje mest eksplisitte uttrykket for ambassadens frieri til sin vertsnasjons befolkning kom i en kommentar fra november 2017, der det avslutningsvis forsikres om «fortsatt kjærlighet og respekt til det norske folk» (Den russiske ambassaden 20171).

Toppunktet i Den russiske ambassadens proaktive informasjonsstrategi må sies å være et dokument som ble publisert 17. februar 2017. Meldingen tar for seg tilstanden i det bilaterale forholdet mellom Norge og Russland og presenteres som en respons på «forespørsler fra mediene, eksperter og statsvitere, spørsmål fra norske statsborgere». Dokumentet preges av høyst uformell og tidvis krass språkbruk samt et antall utilslørte karakteristikker av norske motparter. Ambassaden pekte på den ødeleggende effekten av "[u]saklig og virkelighetsfjern anti-russisk retorikk som brukes av våre norske partnere». Det ble videre hevdet at "propagandastempler som stadig kolporteres (ikke uten hjelp fra myndighetene) av norske medier (...) har det norske publikummet, etter det vi har registrert, blitt veldig leit av [sic]" (Den russiske ambassaden 2017f). Med en sarkasme som neppe er daglig kost i diplomatiske stasjoners skriftlige produksjon, giøres det klart at eventuelle bedringer i det bilaterale forholdet ikke vil komme gratis: «Men ha ingen illusjoner. Vi er ikke på en veldedighetskveld» (ibid.).

Ambassadør Ramisjvili fulgte opp uken etter med å gi et intervju der han påpekte nødvendigheten av en levende debatt: «Vi behøver disse diskusjonene, både i pressen og mellom eksperter, om anti-rakettskjold og Norges deltagelse.» Han oppfordret samtidig norske talspersoner til å endre retorikk: «Norge må slutte å snakke til oss gjennom politiske slagord», og presiserte noe senere: «Vi kan være uenige med mange land både i og utenfor Europa (...) men det betyr ikke at vi må repetere disse 
sakene annethvert minutt, slik Norge gjør.» Avslutningsvis i intervjuet bemerket Ramisjvili at «[d]ialog kan ikke bare være at Norge forteller oss hva vi giør galt» (High North News 2017a og b).

Man kan tolke Den russiske ambassadens ambisjon om å delta i den norske debatten på ulike måter. Noen, som den norske statsministeren, vil se den i lys av en overordnet russisk informasjonsstrategi der Moskvas verdensbilde skal fremmes via ulike kanaler, derunder mediestasjoner som Russia Today og Sputnik:

Så dette oppfatter vi nok litt mer som den tydelige propagandamaskinen som er fra Russland, hvor de ønsker å påvirke og sette sin dagsorden overfor mediene og det norske folk når vi egentlig skal diskutere sikkerhetspolitikk og hvordan vi kan ruste oss sammen i en allianse (VG 2017).

Veien blir da, som vi ser, kort til å avfeie ambassadens meldinger som uttrykk for en propagandistisk forvrengning av virkeligheten som tar sikte på å svekke vestlige lands indre konsensus og opinionens oppslutning om fellesverdier.

Man kan på den annen side forstå uttalelsene som et oppriktig forsøk på å fremme ambassadens tolkninger og situasjonsforståelse for slik å utføre utenriksstasjonens diplomatiske arbeidsoppgave, som er å styrke Russlands posisjon i forholdet til Norge. Både språket og formen har et ukonvensjonelt preg, men ambassadens budskap er ikke i seg selv påfallende ulogisk eller virkelighetsfjernt. Premissene som legges til grunn for ambassadens analyser vil nok møte motstand i en del vestlige land, også Norge. Likevel er Ramisjvili og hans stab i sin fulle rett til å søke å påvirke sine omgivelser i den retning de mener er riktig. I så måte framstår Erna Solbergs avfeiing av Den russiske ambassadens ytringer som propagandistiske vel så udiplomatisk som Ramisjvilis valg av språkdrakt.

\section{Den ikke-eksisterende normaliteten?}

I hvilken retning beveger så det norsk-russiske forholdet seg? Hvilke faktorer bestemmer rammeverket for denne bilaterale forbindelsen? I et forsøk på å definere dette rammeverket, og etablere en grunnleggende erkjennelse som bør ligge til grunn for utformingen av norsk russlandspolitikk, vil jeg ta utgangspunkt i forsvarsminister Ine Marie Eriksen Søreides ovenfor omtalte uttalelser til tv-stasjonen CNN i februar 2017.

Forsvarsministeren erklærte da at vestlige lands forhold til Russland aldri ville bli det samme etter annekteringen av Krimhalvøya. Hun advarte mot forestillingen om at Russlands selvhevdende linje var et fenomen som ville gå over. Forsvarsministeren fastslo at tilstanden i øst-vest-forholdet var endret på en irreversibel måte, idet hun så «no going back to some sort of normality or some sort of back to normal business. Because that normality does not exist» (CNN 2017). Man kan argumentere for at flere aspekter ved dette utsagnet er problematiske: Var forsvarsministeren for drastisk i sin beskrivelse av et nabolands utenrikspolitiske praksis? Med tanke på Norges samarbeidsrelasjoner med Russland var hun nok det, men samtidig var Eriksen Søreides vurdering forståelig om enn ubetenksom. 
Mitt anliggende her er et annet. For å gi uttalelsen mening må forsvarsministerens bruk av begrepet «normalitet» kvalifiseres gjennom en referanse: Hvilken normalsituasjon målte hun dagens Russland mot? Mye tyder på at hennes perspektiv var relativt kortsiktig. Blant annet refererte hun i det samme intervjuet til perioden rundt den georgisk-russiske konflikten i 2008, da Norge og andre vestlige land fremdeles «wanted to see Russia as a strategic partner» (ibid.). Eriksen Søreides normalbilde må dermed antas å ha vært av et Russland som oppfattet sine sikkerhetspolitiske interesser som sammenfallende med vestlige lands strategiske kalkyler, og som søkte samarbeid med USA og andre Nato-land. I så måte kan Eriksen Søreide forstås som et barn av sin tid: Forestillingen om Russlands omfavnelse av liberal-demokratiske verdier og et vestlig verdensbilde var fremherskende i det man må anta var en politisk formativ periode for forsvarsministeren, nemlig 1990-årene. De lange linjene i russisk historie gir imidlertid liten støtte til en slik forventning.

Snarere framstår perioden etter Sovjetunionens sammenbrudd som en historisk anomali. Det er først et lite stykke ut i Putins andre presidentperiode at Russland igjen nærmer seg det som i et lengre historisk perspektiv må oppfattes som den russiske normalsituasjonen, både i innenrikspolitisk og utenrikspolitisk forstand. I et langt historisk perspektiv er Putins sentraliserte og autoritære Russland langt mer normalt enn 1990-årenes desentraliserte kaos under president Boris Jeltsin. På samme måte er russisk selvhevdelse på den internasjonale arena langt mer normalt enn et Russland som passivt gir fra seg innflytelse i sine nærområder. Og, ikke minst, at russiske innenriksmyndigheter fører en restriktiv politikk overfor egen befolkning er historisk sett langt mer normalt enn at de villig mottar vestlig pengestøtte, blant annet fra Norge, for å utvikle et fritt sivilsamfunn og institusjonalisere en liberaldemokratisk rettsstat (Rowe 2017). På bakgrunn av disse betraktningene mener jeg at forsvarsministerens påstand om at «normality does not exist» er uriktig. Vi er tvert imot nærmere en russisk normalsituasjon nå enn noen gang siden Sovjetunionens sammenbrudd i 1992.

Som Eriksen Søreides referanse til vestlige forventninger om Russland som «strategic partner» illustrerer, vil en grunn analyse resultere i urealistiske forventninger om hvordan Russland vil utvikle seg. Eventuelle norske forhåpninger om at russiske politiske ledere med det første vil omfavne demokratiske prinsipper og søke seg i retning av den vestlig-liberale samfunnsmodellen, vil sannsynligvis medføre en virkelighetsfjern russlandspolitikk. Faren er dessuten stor for at norsk utenrikspolitisk retorikk vil bære preg av skuffelse over at Russland til stadighet avviser demokratiets spilleregler og utfordrer internasjonale rettsnormer.

Hvis man derimot tar russisk-sovjetisk historie i betraktning og kombinerer innsikter herfra med inngående kjennskap til dagens økonomiske, politiske og kulturelle forutsetninger, vil man komme langt nærmere en erkjennelse av hva som konstituerer en normalsituasjon, og dermed også en realistisk avklaring av mulighetsrommet i det bilaterale forholdet mellom Norge og Russland. Emosjoner har liten plass i dette bildet, og forventninger om delte verdier er neppe realistiske med det første. 
Bare gjennom en faglig solid analyse vil norske myndigheter, og norsk allmennhet, kunne danne seg et bilde av hva den russiske normalsituasjonen faktisk innebærer. Det bilaterale forholdet mellom Norge og Russland vil måtte finne sin form innenfor denne normaltilstandens rammer. Rammene er, som alltid i den asymmetriske norsk-russiske relasjonen, definert av utviklingen i russisk politikk og av den til enhver tid rådende stemningen i forholdet mellom Moskva og dominerende Nato-medlemmer som USA og Storbritannia. Med utgangspunkt i denne erkjennelsen vil det norske forholdet til den store naboen i mindre grad kunne preges av følelser, og i større grad av fornuft.

\section{Om artikkelen}

Takk til Jørgen Holten Jørgensen, Amund Trellevik, Arild Moe og to anonymiserte fagfeller for gjennomlesing av denne artikkelen. Arbeidet med denne artikkelen er finansiert av det norske Forsvarsdepartementet.

\section{Litteratur}

Aftenposten (2015) «Bør Norge frykte Russland?». 17. mars.

Aftenposten (2015b) «Er Norge bedre forberedt i dag enn 9. april 1940?». 8. april.

Aftemposten (2015c) «Putin straffer Norge med asylsøkere». 23. oktober.

Aldrimer (2015) «Flyktningestrøm trolig russisk hybridkrig». Tilgjengelig på https://www.aldrimer.no/flyktningestrom-er-trolig-russisk-hybridkrig/. Lesedato 10. oktober 2017.

Aldrimer (2016) «Slik jobber russisk etterretning mot Norge». Tilgjengelig på https:/www.aldrimer.no/slikjobber-russisk-etterretning-mot-norge/. Lesedato 11. oktober 2017.

Bartles, Charles K. (2016) "Getting Gerasimov Right». Military Review: The Professional fournal of the U.S. Army 96 (1): 30-38.

Bones, Stian (2007) «I oppdemmingens grenseland. Nord-Norge i den kalde krigen 1947-70». Avhandling levert for graden Doctor artium. Tromsø: Universitetet i Tromsø.

Brende, Børge (2017) «Naboskap og storpolitikk». Kronikk i Nordlys. 24. august.

Charap, Samuel \& Timothy J. Colton (2017) Everyone Loses. The Ukraine Crisis and the Ruinous Contest for PostSoviet Eurasia. London: Routledge.

CNN (2015) «Norway: We are faced with a different Russia». Intervju med Ine Marie Eriksen Søreide, 26. februar. Tilgjengelig på http://edition.cnn.com/2015/02/25/world/amanpour-norway-ine-eriksen-soreide/ index.html. Lesedato 28. september 2017.

Dagbladet (2015) «Nye og gamle fiender truer Russland». 16. mars.

Dagbladet (2015b) «Trusler og risikoer for Norge i et endret sikkerhetsbilde». 16. mars.

Dagbladet (2015c) «Putin viser muskler med 250 militærfly i lufta». 27. mai.

Dagsavisen (2015) «Advarer mot russisk splitt og hersk». 10. november.

Den russiske ambassaden (2017a) «Russland-Nato». Pressemelding av 17. januar 2017. Tilgjengelig på http:// www.norway.mid.ru/press_17_003.html. Lesedato 16. oktober 2017.

Den russiske ambassaden (2017b) «Vedrørende missilforsvar». Pressemelding av 17. januar 2017. Tilgjengelig på http://www.norway.mid.ru/press_17_004.html. Lesedato 16. oktober 2017.

Den russiske ambassaden (2017c) «Kommentaren av Russlands ambassade i Norge for masse media i forbindelse med statlig kringkastingsselskap 'NRK's material av 27. januar 2017 om 'innblanding' i arbeid av Nobelkomiteen [sic]». Pressemelding av 28. januar 2017. Tilgjengelig på http://www.norway.mid.ru/ press_17_005.html. Lesedato 16. oktober 2017.

Den russiske ambassaden (2017d) «Kommentar av Russlands Ambassade i Norge i forbindelse med utsettelse av et planlagt besøk av Stortingets delegasjon til Moskva 2.-3. februar 2017». Pressemelding av 2. februar 2017. Tilgjengelig på http://www.norway.mid.ru/press_17_006.html. Lesedato 16. oktober 2017.

Den russiske ambassaden (2017e) «Kommentar av Russlands Ambassade i Norge vedrørende årlige vurderingen av Politiets sikkerhetstjeneste». Pressemelding av 2. februar 2017. Tilgjengelig på http://www.norway. mid.ru/press_17_008.html. Lesedato 16. oktober 2016. 
Den russiske ambassaden (2017f) «Kommentar av Russlands Ambassade i forbindelse med situasjonen i det bilaterale forholdet». Pressemelding av 17. februar 2017. Tilgjengelig på http://www.norway.mid.ru/ press_17_011.html. Lesedato 16. oktober 2017.

Den russiske ambassaden (2017g) «Kommentar fra Den Russiske Føderasjons ambassade i Norge til Dagbladet i forbindelse med Norges og USAs vurdering av omfanget av norsk bidrag til NATOs missilforsvar». Pressemelding av 9. mars 2017. Tilgjengelig på http://www.norway.mid.ru/press_17_013.html. Lesedato 16. oktober 2017.

Den russiske ambassaden (2017h) «Kommentar fra Russlands Ambassade i forbindelse med innreiseforbud for sjefredaktøren i Independent Barents Observer Thomas Nielsen». Pressemelding av 1. mars 2017. Tilgjengelig på http://www.norway.mid.ru/press_17_014.html. Lesedato 16. oktober 2017.

Den russiske ambassaden (2017i) «Kommentar av Russlands Ambassade i Norge i forbindelse med gjennomføring av øvelsen 'Joint Viking'». Tilgjengelig på http://www.norway.mid.ru/press_17_015.html. Lesedato 28. september 2017.

Den russiske ambassaden (2017j) «Kommentar av Russlands ambassade i Norge til 'NRK' vedrørende situasjonen med flyktninger på den russisk-norske grensen i 2015». Pressemelding av 28. mars 2017. Tilgjengelig på http://www.norway.mid.ru/press_17_018.html. Lesedato 16. oktober 2017.

Den russiske ambassaden (2017k) «Kommentar av Russlands Ambassade i Norge i forbindelse med uttalelser til lederen av Politiets sikkerhetstjeneste (PST)». Pressemelding av 2. oktober 2017. Tilgjengelig på http:// www.norway.mid.ru/press_17_032.html. Lesedato 16. oktober 2017.

Den russiske ambassaden (20171) «Kommentar fra Russlands Ambassade i Norge til 'NRK' vedrørende russiske 'hybridkriger'». Pressemelding av 22. november 2017. Tilgjengelig på http://www.norway.mid.ru/ press_17_040.html. Lesedato 13. desember 2017.

Endringer i forskrift (2016) «Forskrift om endringer i forskrift 3. februar $1995 \mathrm{nr} .96$ om bortvisning og utvisning av personer fra Svalbard». Tilgjengelig på https://ovdata.no/dokument/LTI/forskrift/2016-08-26-1009. Lesedato 12. oktober 2017.

Eriksen, Knut Einar og Helge Øystein Pharo (1997). Kald krig og internasjonalisering 1945-1965. Oslo: Universitetsforlaget.

Etterretningstjenesten (2015) «Fokus 2015. Etterretningstjenestens vurdering». Oslo: Etterretningstjenesten.

Etterretningstjenesten (2016) «Fokus 2016. Etterretningstjenestens vurdering av aktuelle sikkerhetsutfordringer». Oslo: Etterretningstjenesten.

Forsvaret (2017) «Innsats» 6/2017, bilag til Aftenposten.

Gerasimov, Valerij (2013) «Tsennost nauki v previdenii». Voenno-promysjlennyj kurer 8: 1-3.

Gessen, Masha (2017) «Russia, Trump \& Flawed Intelligence». The New York Review of Books. Tilgjengelig på http://www.nybooks.com/daily/2017/01/09/russia-trump-election-flawed-intelligence/. Lesedato 11. november 2017.

Goldin, Vladislav Ivanovitsj \& Jens Petter Nielsen (red.) (1996) Frykt og forventning. Russland og Norge i det 20. århundre. Arkhangelsk: Pomoruniversitetets forlag.

Heier, Tormod \& Anders Kjølberg (red.) (2015) Norge og Russland. Sikkerhetspolitiske utfordringer i nordområdene. Oslo: Universitetsforlaget.

High North News (2017a) «Russlands ambassadør advarer: Rakettskjold vil sette Norges grenser i fare». Tilgjengelig på http://www.highnorthnews.com/russlands-ambassador-advarer-rakettskjold-vil-sette-norgesgrenser-i-fare-ny/. Lesedato 17 . oktober 2017.

High North News (2017b) «Russlands ambassadør: -Vi ønsker å gjenopprette det normale naboskapet». Tilgjengelig på http://www.highnorthnews.com/russlands-ambassador-vi-onsker-a-gjenopprette-det-normalenaboskapet/. Lesedato 17. oktober 2017.

Holtsmark, Sven G. (red.) (2015) Naboer i frykt og forventning. Norge og Russland 1917-2014. Oslo: Pax forlag.

Hønneland, Geir (2016) «En kalkulerende aktør?». Kronikk i FiskeribladetFiskaren, 5. februar 2016.

Hønneland, Geir \& Lars Rowe (2010) Nordområdene - hva nå? Trondheim: Tapir Akademisk Forlag.

Klima- og miljødepartementet (2015) «Samarbeid med Russland om felles miljøutfordringer». Tilgjengelig på www.regjeringen.no/no/aktuelt/samarbeid-med-russland-om-felles-miljoutfordringer/id2465417/. Lesedato 11. august 2017.

Minerva (2017) «Sentrale Frp-ere slutter seg til Hagens Putin-støtte». Tilgjengelig på https://www.minervanett. no/sentrale-frp-ere-slutter-hagens-putin-stotte/. Lesedato 29. september 2017.

Moe, Arild \& Lars Rowe (2016) «Asylstrømmen fra Russland til Norge i 2015: Bevisst russisk politikk?» Nordisk Østforum 30 (2): 80-97.

Nielsen, Jens Petter (1991) «Ønsket tsaren seg en isfri havn i nord?» Historisk tidsskrift 4/1991: 604-621. 


\section{0 | LARS ROWE}

Nilssen, Andrea Sofie (2015) «Norske premisser. En diskursanalyse av Regjeringens og mediers oppfatning av Russland». Upublisert masteroppgave. Oslo: Universitetet i Oslo.

Nordlys (2017) «US marines trener vinterkrig i Finnmark». Leder i Nordlys, 25. januar.

NRK (2017a) «Russisk hackerangrep mot Norge». Tilgjengelig på https://www.nrk.no/nyheter/russisk-hackerangrep-mot-norge-1.13359038. Lesedato 11. oktober 2017.

NRK (2017b) «Hva har skjedd med vennskapet til Russland?». Tilgjengelig på https://www.nrk.no/finnmark/xl/ hva-har-skjedd-med-vennskapet-til-russland_-1.13414727. Lesedato 10, oktober 2017.

NRK (2017c) «PST bekrefter russisk informasjonsoperasjon mot Norge for første gang». Tilgjengelig på https:// www.nrk.no/norge/xl/pst-bekrefter-russisk-informasjonsoperasjon-mot-norge-for-forste-gang-1.13339968. Lesedato 17. oktober 2017.

NRK.no (2015) «Rogozin på omstridt Svalbard-besøk». Samleside tilgjengelig på https:/www.nrk.no/nyheter/ rogozin-pa-omstridt-svalbard-besok-1.12317952. Lesedato 12. oktober 2017.

NRK Finnmark (2016) «Sentrale folk i Finnmark ber PST ryke og reise». Tilgjengelig på https://www.nrk.no/ finnmark/_-sentrale-folk-i-finnmark-ber-pst-ryke-og-reise-1.12805354. Lesedato 11. oktober 2017.

Office of the Director of National Intelligence (2017) «Intelligence Community Assessment: Assessing Russian Activities and Intentions in Recent US Elections", rapport utgitt 6. januar 2017. Tilgjengelig på https:// assets.documentcloud.org/documents/3254237/Russia-Hack-Report.pdf. Lesedato 11. November 2017.

Politiets sikkerhetstjeneste (2017) "Trusselvurdering 2017». Oslo: Politiets sikkerhetstjeneste.

Pomerantsev, Peter (2014) Nothing is true and everything is possible. The surreal heart of the new Russia. New York, NY: Public Affairs.

Putin, Vladimir (2007) «Prepared Remarks at 43rd Munich Conference on Security Policy». Tilgjengelig på http:/www.washingtonpost.com/wp-dyn/content/article/2007/02/12/AR2007021200555.html. Lesedato 18. april 2017.

Putin, Vladimir (2014) «Obrasjtsjenie Prezidenta Rossijskoj Federatsii». Tilgjengelig på http://www.kremlin.ru/ events/president/transcripts/20603. Lesedato 16. oktober 2017.

Renz, Bettina (2016) «Russia and 'hybrid warfare'». Contemporary Politics 22 (3): 283-300.

Renz, Bettina \& Hanna Smith (2016) «Russia and hybrid warfare - going beyond the label». Aleksanteri Papers $1 / 2016$

Rowe, Lars (2017) «Mot en ny normalitet». Tidsskriftet Ottar. 314 (1): 58-63.

Skedsmo, Pål (2010) Russisk sivilsamfunn og norske hjelpere. Trondheim: Tapir Akademisk Forlag.

Svalbardposten (2015) «Russland protesterer mot nye Svalbard-regler». Tilgjengelig på http://svalbardposten.no/ index.php?page=vis_nyhet\&NyhetID=6190. Lesedato 12. oktober 2017.

Svalbardtraktaten (1920) «Traktat mellem Norge, Amerikas Forente Stater, Danmark, Frankrike, Italia, Japan, Nederlandene, Storbritannia og Irland og de britiske oversjøiske besiddelser og Sverige angående Spitsbergen [Svalbardtraktaten]». Tilgjengelig på https://lovdata.no/dokument/NL/lov/1920-02-09. Lesedato 12. oktober 2017.

Søreide, Ine Marie Eriksen (2017) «En balansert sikkerhetspolitikk». Debattinnlegg i Nordlys, 28. januar.

Tsygankov, Andrei P. (2010) Russia's Foreign Policy. Change and Continuity in National Identity. Lanham, Maryland: Rowman \& Littlefield.

TV2 (2015) «Slik kan Russland gå til angrep på Norge». 3. juni.

TV2 (2015b) «Ekspert: -Russland øvde på å innta Nord-Norge». 25. juni.

Vedomosti (2016) "Bolsje, tsjem osjibka». Leder, 17. mars.

$V G$ (2017) "Erna Solberg kaller den russiske kritikken for propaganda». Verdens Gang, 17. februar.

Zygar, Mikhail (2016) All the Kremlin's Men. Inside the court of Vladimir Putin. New York, NY: Public Affairs.

Zygar, Mikhail (2017) Vsia kremlevskaja rat. Kratkaja istorija sovremennoj Rossii. Moskva: Intellektualnaja literatura. 